\title{
Os caminhos da salvação e da condenação eternas: a presença da alegoria na História do Predestinado Peregrino e de seu Irmão Precito (1682), de Alexandre de Gusmão
}

\author{
The paths of salvation and eternal condemnation: The presence of the \\ allegory in the History of the Elected Pilgrim and his Brother Precito (1682), \\ de Alexandre de Gusmão
}

José Adriano Filho*

\begin{abstract}
Resumo
As repercussões que os ecos do Concílio de Trento (1546-1563) e o movimento da Contrarreforma tiveram em nível da produção artística no mundo católico, e as intenções pedagógico-didáticas subjacentes à sua composição estão fundamentadas na crença de que a arte poderia ser um instrumento eficaz de reconversão dos fiéis e de doutrinamento nos valores da fé católica. Considerando isto, este artigo mostra como a alegoria foi utilizada como instrumento de interpretação e construção do discurso religioso na obra História do Predestinado Peregrino e de seu Irmão Precito. O livro é uma narrativa alegórica que, ao apresentar a história de dois irmãos peregrinos, naturais do Egito, de onde partiram com a intenção de fazer fortuna - um vai para Jerusalém, o outro para Babilônia, dá continuidade ao modelo aberto pela tradição medieval que valorizava a viagem, especialmente o caminho percorrido em busca da salvação. A predisposição da alegoria para veicular conceitos abstratos através de visualizações concretas, aliada a uma forma de expressão indireta, tornaram-na um poderoso instrumento apologético, didático e recreativo para aquela época.
\end{abstract}

Palavras-chave: religião e literatura; peregrinação; alegoria; contrarreforma.

\begin{abstract}
The repercussions of the echoes of the Council of Trent (1546-1563), the Counter Reform movement, and the repercussions they had on the artistic production in the Catholic world. The pedagogical-didactic intents behind its composition are grounded on the belief that art could be an effective tool for reconverting of the faithful and for indoctrination in the values of the Catholic faith. Considering that, this paper aims at presenting the way allegory became an important tool for the interpretation and construction of religious discourse, as we can see in the History of the Elected Pilgrim and his Brother Precito. The book is an allegorical narrative that presents the history of two pilgrim brothers born in Egypt from where they set out with the intention of making a fortune (one brother goes to Jerusalem, and the other one goes to Babylon). In this way, the book presents continuity with the medieval pattern that highlights the journey, especially the path for salvation. The readiness of allegory to transmit abstract concepts through concrete visualizations allied to a form of indirect expression made it a powerful, didactic, apologetic, and entertaining tool for that time.
\end{abstract}

Keywords: religion and literature; pilgrimage; allegory; counter-reform.

Artigo recebido em 06 de setembro de 2014 e aprovado em 23 de março de 2015.

*Doutor em Ciência da Religião e Professor da Faculdade Unida de Vitória. País de origem: Brasil. E-mail: j.adriano1@uol.com.br 


\section{Introdução}

O livro História do Predestinado Peregrino e de seu Irmão Precito ${ }^{1}$ é uma narrativa alegórica que foi escrita pelo Pe. Alexandre de Gusmão, importante liderança dos jesuítas no Brasil do século XVII e início do século XVIII. Ele foi publicado pela primeira vez em 1682, numa época em que a cultura intelectual do país era quase que exclusivamente eclesiástica. Os missionários que atuavam no Brasil procuravam também adaptar a doutrina religiosa na qual haviam sido educados para os fins práticos de seu empreendimento no Novo Mundo, utilizando, para tal, diversos gêneros literários: a "escrita constituiu-se, nas práticas jesuíticas de ensino e catequese, segundo gêneros utilitários: cartas, o auto, o poema didático, o sermão, o catecismo, a doutrina, até a própria gramática” (AGNOLIN, 2007, p. 77). Esta escrita é “ordenada retoricamente, isto é, há nela uma íntima fusão entre retórica e letras antigas, fundidas inevitavelmente com a teologia política da neoescolástica” (AGNOLIN, 2007, p. 77).

O apelo de cristianização da obra de arte era também obrigatório neste período, o que acabou por resultar numa valorização das formas literárias que, em consonância com o Concílio de Trento (1545-1563), instruíssem e integrassem o povo na doutrina católica. Segundo a teoria da arte da Contrarreforma, a arte deveria divertir e educar os leitores nos princípios da fé cristã. A atividade artística revestia-se de intenções pedagógico-didáticas fundadas na crença de que a arte poderia constituir um instrumento eficaz de reconversão dos fiéis e de doutrinamento nos valores da fé católica. A arte não era concebida somente a partir da tradição aristotélica e horaciana do delectare ("deleitar”) e docere ("ensinar”), mas envolvia também outro aspecto que altera profundamente a natureza intelectualista do docere: o movere (“comover”) (MOREIRA, 2006, p. 25-35):

\footnotetext{
${ }^{1}$ GUSMÃO, Alexandre de. História do Predestinado Peregrino e de seu Irmão Precito. 2a ed. Évora: Editora da Universidade, 1685. Disponível em: http://www.archive.org/details/historiadopredes00gusm. A edição moderna da obra, sob a coordenação da professora Marina Massimi, da Universidade de São Paulo - Ribeirão Preto, foi publicada recentemente: A novela História do Predestinado Peregrino e de seu Irmão Precito (1682). Compêndio de Saberes Antropológicos e Psicológicos dos Jesuítas no Brasil Colonial. São Paulo: Edições Loyola, 2012. As citações da obra deste artigo são feitas de acordo com a edição moderna.
} 
Comover o homem, não o convencendo de forma demonstrativa, mas afetando-o, de modo que sua vontade seja acionada: está é a questão. Só assim se consegue arrastar o indivíduo, suscitando sua adesão a uma atitude determinada, e somente por essa via se logra mantê-lo solidário. [...] Não basta dizer que o Barroco se mantém fiel à temática, segundo a tradição aristotélica e horaciana, do delectare-docere, fundindo as duas partes numa só tendência. Esquecer o terceiro aspecto que encerra e que altera profundamente a natureza intelectualista do docere é não tocar no cerne da questão. Referimo-nos ao "comover". Que este último seja aquilo que deve ser alcançado é o aspecto novo, pelo menos em seu papel decisivo do Barroco: por em marcha a vontade, apelando aos motores que a acionam, os quais não são de natureza puramente intelectual (MARAVALL, 1997, p. 149).

A alegoria foi utilizada para atingir estes objetivos, pois a sua "predisposição para veicular conceitos abstratos através de visualizações concretas, aliada a uma forma de expressão indireta, tornaram-na um poderoso instrumento apologético e didático que, ao mesmo tempo, manifesta potencialidades recreativas para a época [...]" (MOREIRA, 2006, p. 46). Nos primeiros séculos do cristianismo, os Pais da Igreja já haviam utilizado a interpretação alegórica das Escrituras com o objetivo de justificar o uso da alegoria pagã em chave cristã; o procedimento alegórico tornará não só lícita, mas até mesmo "necessária essa mediação e a utilização da cultura clássica será aquela realizada pela interpretação alegórica”, possibilitando a "apropriação e a transformação da cultura clássica pela cristã" (AGNOLIN, 2007, p. 188-190; LUBAC, 1998, p. 211-224). No século XVI, esta cultura adquiriu uma nova configuração, sendo justamente este o contexto de trabalho da ordem jesuítica, que também fundamentava sua pedagogia na importância fundamental da cultura clássica (AGNOLIN, 2007, p. 190).

Considerando estes aspectos, o presente artigo mostra como a alegoria foi utilizada como recurso de construção e de interpretação na História do Predestinado Peregrino e de seu Irmão Precito, que apresenta a história de dois irmãos peregrinos, naturais do Egito, de onde partiram com a intenção de fazer fortuna - um vai para Jerusalém, o outro para Babilônia. Cada um dos irmãos peregrinos passa por seis cidades, as quais indicam os caminhos da salvação e da condenação eternas como duas alternativas que se colocam a cada indivíduo. A 
predisposição da alegoria para veicular conceitos abstratos através de visualizações concretas, aliada a uma forma de expressão indireta, tornaram-na um poderoso instrumento apologético, didático e recreativo para aquela época.

\section{A História do Predestinado Peregrino e de seu Irmão Precito e a tradição das narrativas alegóricas de peregrinação}

A representação da vida humana na terra como peregrinação física ou espiritual da alma humana, como degredo de uma pátria celestial, tem uma longa história na tradição literária do Ocidente. Este tema tem grande suporte na tradição bíblica, nos primeiros Pais da Igreja, na Cidade de Deus, de Santo Agostinho, tendo-se tornado lugar comum no pensamento medieval, no Renascimento, e vindo até os nossos dias. O neoplatonismo lhe forneceu a configuração necessária, cuja ressonância se faz sentir em todos esses períodos. Em seu ensino, a Igreja também mantinha presente a lembrança de que a vida humana não é mais que um trânsito precário pelo "vale de lágrimas”. A História do Predestinado Peregrino e de seu Irmão dá continuidade a este modelo que valorizava a viagem, especialmente o caminho percorrido em busca da salvação: a busca do homo viator, caminhante, que procura transcender sua condição física, terrena, num movimento de retorno e de restauração de uma pátria perdida (TUCKER, 2003, p. 54-56):

\footnotetext{
Enquanto nesta vida militamos, somos todos como desterrados, ou como peregrinos, porque ausentes de nossa Pátria, que é o Céu; ou como desterrados dela pelo pecado de Adão ou como caminhantes para ela pelos merecimentos de Cristo; vivemos aqui neste vale de lágrimas ou como desterrados ou como peregrinos. Expressamente no-lo diz S. Paulo: Dum sumus in corpore, peregrinamur a Domino. O que nos importa é caminhar para a nossa pátria, saber os caminhos e procurar a entrada, para o que nos servirá de guia o exemplo da história, ou parábola seguinte (GUSMÃO, 2012, p. 59).
}

A obra se divide em seis partes, o número de cidades por onde passaram os dois irmãos peregrinos até chegarem a Jerusalém e à Babilônia: Predestinado passa por Belém, Nazaré, Betânia, Cafarnaum, Betel, chegando finalmente a Jerusalém; Precito passa por Bethaven, Samaria, Bethoron, Éden, Babel, até alcançar 
Babilônia. Inscrita na tradição alegórica, a obra apresenta os caminhos para o céu e o inferno, ou seja, conforme os passos dessa vida, as pessoas se salvam ou se condenam (SANTOS, 2004, p. 590-591). Ela se "auto-explica e se autojustifica, qual um corpus doutrinário sujeito à fé e evidente por si próprio” (MOISÉS, 2001, p. 200):

Contém esse livro a história de dois Irmãos Peregrinos, que do Egito, donde eram naturais, com o ânimo de melhorar fortuna, partiram para terras da Palestina. Vem a ser em Parábola a história de todo aquele que seguindo os passos que nesta vida leva, se seguindo o caminho, que tomou: ou se salva, ou se condena (GUSMÃO, 2012, p. 58-59).

Apresentada como "parábola”, toda "a estrutura da obra está construída com base no pressuposto da manifesta existência de uma dupla leitura do enunciado ficcional" (AUGUSTO, 2010, p. 376). A história de Peregrino e de Precito "obriga inequivocamente, pelo fato de a alegoria se apresentar no seu grau mais elevado, a uma segunda leitura de caráter moral e doutrinário” (AUGUSTO, 2010, p. 376):

De tal modo essa necessidade de descodificação era premente, sendo mesmo concretizada pelo narrador ao longo da obra, na descrição das personagens e dos espaços, que a novidade não se encontra no desenlace da narrativa. $\mathrm{O}$ enredo está firmemente orientado para um desfecho que não podia ser desconhecido, uma vez que correspondia a uma canônica configuração doutrina e moral, mas que podia primar pela novidade dos conceitos e analogias. É nesta linha dupla, entre sentido figurado e sentido real podia apresentar rasgados vôos de imaginação, mas não podia oferecer dúvidas na sua interpretação, do que decorre a cuidada escolha das personagens e do espaço em que progridem, óbvias concretizações dos conceitos de um catecismo seguido ponto a ponto (AUGUSTO, 2010, p. 376).

De acordo com Sara Augusto, “definida a dupla leitura do enunciado alegórico, torna-se necessário definir as linhas mestras que estruturam o enredo, elas próprias significativas em termos de sentido moral” (AUGUSTO, 2010, p. 376377). Primeiro, “a antítese constitui o eixo organizador, estabelecendo-se logo a partir do próprio título da narrativa, mantendo esse protagonismo até a definição do destino final das personagens". Segundo, “o progresso das personagens desenvolve-se pelo espaço ficcional, configurado na viagem nos dois irmãos 
peregrinos, uma vez que cada um segue seu caminho, desenhando mapas e definindo veredas em polos opostos" (AUGUSTO, 2010, p. 377). A obra se constitui, portanto, pelos "atos dos dois irmãos peregrinos e ditames do narrador ou de outro figurante alegórico"; apresenta uma "série de atos individualizados, mas a ação estrutura-se em células dramáticas subsequentes e utiliza alegorias em vez de personagens reais" (AUGUSTO, 2010, p. 377).

Os "episódios ou células dramáticas que identificam a novela são substituídos pelos passos dois irmãos, cada qual numa direção, e o catecismo ensinado parabolicamente, por meio de situações equivalentes às do viver comum, mas protagonizados por alegorias" (AUGUSTO, 2010, p. 377). A doutrina é transmitida de forma detalhada, como se o autor quisesse "transpor a Bíblia e os dogmas cristãos em forma de alegoria narrativa: o tom de quem conta para ser lido em voz alta serve ao propósito doutrinador, e a ficção transforma-se em literatura engajada, a favor do pensamento católico” (MOISÉS, 2001, p. 201):

Dois protagonistas realizam as façanhas ilustrativas da doutrina, num maniqueísmo que trai a ideologia medieval e uma aparente dualidade estrutural: na verdade, Predestinado e Precito praticam ações paralelas, ao contrário de D. Quixote e Sancho Pança, que peregrinam juntos, mas a ênfase é posta no primeiro. Como se tratava de induzir o fiel à prática das verdades mostradas na ação do caminhante cristão, o texto sempre se detém pouco em Precito: mais de uma vez, um capítulo que parecia exclusivo do Precito passa a concentrar-se, logo volvidos os primeiros parágrafos, em Predestinado. A estrutura da obra reflete o intuito do narrador: Precito funciona como superfície de contraste para a doutrina que se pretende verbalizar. E somente não se concretiza como novela de uma só personagem porque o conflito de Predestinado apenas ganha relevo quando em confronto com o de Precito (MOISÉS, 2001, p. 201202).

\section{Os dois irmãos peregrinos e seus respectivos itinerários}

Predestinado Peregrino e seu Irmão Precito partem da cidade de Gerson, que significa "desterro", situada no Egito, o "mundo", e trilham caminhos diferentes, sendo que "cada um deles percebe e valoriza de forma antagônica as possibilidades que lhe são apresentadas" (MOREIRA, 2006, p. 194-196): 
Enfadados das tribulações do Egito, e dos enganos de seus naturais [...] resolveram deixar o Egito, que é o mundo, e buscar outra Cidade, para nela fazerem com sua família sua habitação. [...] Assim, prevenidos, os nossos peregrinos, despedidos do Egito, e todas suas esperanças, saíram por uma porta que só se abre para sair, não para entrar, que chama abnegação de tudo, porque aquele que uma vez resolve deixar o mundo há de ser para nunca mais voltar a ele (GUSMÃO, 2012, p. 61-62).

A realidade é a mesma, mas cada um dos viajantes a vê com olhos diferentes:

"a Precito lhe pareceu o caminho breve, a Predestinado lhe pareceu mui prolongado":

Saíram, pois, Predestinado e Precito e caminharam por uma estrada comum, que chamam Vida cheia de mil despenhadeiros, enfadonhos de passar, que se chamam Embaraços da vida. Ainda que a Precito o caminho lhe pareceu breve, a Predestinado lhe pareceu muito prolongado. [...] Não faltaram por estra mata da Vida algumas feras, como Lobos, Leões, Raposas, que são as paixões da vida, que, de algum modo, detinham o passo dos peregrinos [...] Sucedeu, pois, que duvidosos ambos por onde fariam seu caminho, se pelo vale, se pelo outeiro, [...] eis que vêm diante de si dois mancebos de estremada gentileza, se bem pareciam um de boa, e outro de má condição, os quais diziam serem grandes Cosmógrafos no caminho de Babilônia, e de Jerusalém [...] os quais saudando amigavelmente aos peregrinos, lhes perguntaram: Homens de bem, para onde é vossa jornada? Respondeu Predestinado, que para Jerusalém, Precito, para Babilônia. [...] Apartaram-se aqui os dois irmãos, para nunca mais se verem juntos (GUSMÂO, 2012, p. 62-64).

Essa assimetria de pontos de vista determina que os irmãos se apartem, após visitarem em conjunto o "Vale de lagrimas" e o "Vale da Ocasião, que ainda que à vista parecia deleitoso, era porém de ruins ares, e pior clima, porque os demais, que nele se detinham muito tempo, pereciam". Predestinado escolhe um "outeiro difícil”, por onde "longe se vai” para Jerusalém, enquanto Precito escolhe um "vale florido”, que o conduzirá à Babilônia:

Essas informações iniciais criam no leitor a expectativa que acompanha a narrativa dos progressos feitos pelos dois irmãos no decurso da peregrinação que assim iniciam. Tal expectativa não será frustrada, muito embora o relato não incida sobre peripécias de um percurso com equivalência na realidade extra-textual. Com efeito, a antinomia bíblica representada pela oposição entre Jerusalém e Babilônia (os dois destinos finais dos peregrinos) adquire significado apenas num plano alegórico, já que a primeira das cidades, a civitas Dei, é uma sinédoque daquilo que 
pode ser referido como o "domínio do Bem", enquanto Babilônia, por oposição, se conota com a representação do Mal. O itinerário que as duas personagens e respectivos séquitos vão percorrer resulta, assim, não numa deslocação pelo espaço-tempo empiricamente mensurável, mas sim numa caminhada interior pela estrada a 'que chamam vida' (MOREIRA, 2006, p. 197).

Cada um dos irmãos peregrinos passa por seis cidades, sem jamais se encontrarem; seus itinerários seguem esquemas equidistantes, sendo cada um deles o reverso do outro. As etapas que eles percorrem correspondem às seis partes da obra, sendo, talvez, uma tentativa de manter certa equivalência entre as divisões formais do texto e o conteúdo moral de cada uma destas partes. Há uma paridade simbólica entre os caminhos que os dois peregrinos passam e as etapas de seus respectivos percursos são apresentadas de forma intercalada: "Vai repartido [o livro] em seis partes, porque tantas são as Cidades que o Predestinado andou até chegar a Jerusalém, em que se representava a Bem-aventurança e as seis cidades onde pisou Precito, até chegar a Babilônia, que significa o Inferno" (GUSMÃO, 2012, p. 59). Além disso, o "narrador desacelera o ritmo da narração ao apresentar a história de Predestinado, demora na descrição dos espaços por onde ele se move, multiplica as personagens que com ele interagem, relata diálogos mantidos em diversas situações das quais há que retirar ensinamentos morais, alonga-se na explanação dos preceitos doutrinários e sintetiza-os em 'memoriais de ditames' para uso diário" (MOREIRA, 2006, p. 197-198, 206).

Predestinado passa por seis cidades, que correspondem a etapas no caminho da salvação (MOREIRA, 2006, 198-201):

a) Belém, "entre as principais de Judeia, de nenhuma sorte a menor, Cidade onde nasceu nosso Rei, com cuja vista sumamente se alegrou", governada por "um nobre Senhor do mesmo nome Desengano, casado com uma ilustríssima e santa Senhora chamada Verdade", Predestinado conhece o desengano do mundo, sem o qual "não é possível caminhar seguro a Jerusalém". O "desengano do mundo" era um lugar comum na literatura dos séculos XVI e XVII. O “engano do mundo" é a crença de que o mundo temporal e corruptível é perpétuo e autônomo, a ilusão de que o mundo de aparências, na realidade passageiro, é uma verdade a ser 
valorizada e cultivada. O “desengano" refere-se, então, à descoberta e a entrega à verdade divina, sendo um passo importante do Peregrino rumo à salvação:

Assim, disposto desta sorte levou Desengano Predestinado a uma atalaia mui alta, que chamam Superior Consideração, da qual se descobria o mundo todo, e da qual, dizem, descobria o Sábio o engano, e a vaidade de todas as coisas do mundo quando disse: Vanitas vanitatum, O ommia vanitas. Predestinado tirou uns óculos que do Egito trouxera, que chamam Olhos da carne, pelos quais se veem as coisas mui de outra sorte que são [...]. Aplicou, pois, os olhos Predestinado, e com eles descobriu o mundo todo com toda sua formosura, riquezas, honras, deleites, e mais variedades de coisas. [...] E descendo em particular a considerar as riquezas que lhe pareciam cousa de grande estimação, pela muita que delas faziam os homens, e disse em seu coração uma grande coisa deve ser o dinheiro, a quem todos obedecem! [...] Já Predestinado se ia esquecendo do que havia visto, e considerando naquelas quatro salas do Desengano e dos maus exemplos que ali vira, já seu coração com a vista das coisas presentes se ia afeiçoando às coisas vãs e aos enganos do mundo: quando sua esposa Razão e seus filhos Bom Desejo e Reta Intenção advertiram, se não esquecesse seguir os passos de Desengano, que estava presente, o qual falando com palavras ásperas lhe disse: que fazes Peregrino? Já te esqueces do teu nome e de tua profissão? Não costumam os peregrinos, que são Predestinados, ver as coisas do mundo com os olhos da carne, senão de espírito: deixa estes óculos para os Precitos, a quem o mundo engana, e sua vaidade, porque veem suas coisas com os olhos da carne. [...] Viu como o mundo justifica suas mentiras, acredita seus enganos, vitupera a virtude e desacredita o verdadeiro e, finalmente, então, viu claramente quão falsas eram todas as esperanças do mundo, quão enganosas suas promessas, que só o eterno era verdadeiro, e todo o temporal engano" (GUSMÃO, 2012, p. 75-78).

b) Nazaré, "porque lhe haviam afirmado que por Nazaré se ia direito a Jerusalém, e que assim o havia feito Cristo, nosso Mestre, quando de Belém, onde nascera, se foi logo morar a Nazaré, na qual viveu tantos anos que veio a ser chamado Nazareno". Nazaré era uma cidade governada por "um fidalgo pio e devoto, chamado Culto Divino, casado com uma Santa e honesta Senhora, chamada Religião e, por isso, os cidadãos todos de Nazaré eram Religiosos e Nazaré, o símbolo da Religião” (GUSMÃO, 2012, p. 83).

c) Betânia, que significa "Casa de Obediência, pela qual lhe haviam dito em Nazaré que havia de passar e ainda morar necessariamente, se queria chegar a Jerusalém”, Predestinado e a família são recebidos pelos respectivos governadores, Preceito e Obediência, "os quais se alegraram muito de ver a Predestinado em 
Betânia pelo caminho dos Mandamentos de Deus e deram logo ordem para que tivesse audiência em Palácio", isto é, o "Palácio do Decálogo" que Predestinado visita para conhecer os seus habitantes, isto é, os Mandamentos de Deus (GUSMÃO, 2012, p. 106-1-7).

d) Cafarnaum, governada por "um severo fidalgo por nome Rigor Santo, casado com uma severa Matrona chamada Penitencia Justa”. Nesta cidade, arrepende-se do seu passado, confessa as suas culpas e faz penitência em desconto dos seus pecados. Predestinado acha-se frente a "dois caminhos", "vendo-se perplexo de qual era o verdadeiro para Jerusalém”, sendo acudido por "um mancebo que se chamava Evangelho", que o esclarece sobre as opções que se lhe deparavam: "um dos caminhos, que se chamava da Penitencia, ia para Cafarnaum (“Campo de Penitência”), o outro, “que se chamava dos Conselhos”, ia para Betel, que se interpreta “Casa de Deus” (GUSMÃO, 2012, p. 133-136).

e) Betel ("Casa de Deus"), localizada num alto monte, chamado "Cume de perfeição", onde habitava a "Caridade, ou a Perfeição, que Predestinado buscava”. Aí, Predestinado dedica-se ao cultivo da terra onde tem raiz a "árvore de Nazaré ('vida espiritual'), cujas flores chamam Desejos, as frutas Obras, e as folhas Intenções: com esta diferença porem, que os Incipientes comem do primeiro ramo, a que chamam Vida Purgativa, os Proficientes comem do segundo ramo, que chamam Vida Iluminativa, e os Perfeitos comem do terceiro ramo, que se chama Vida Unitiva” (GUSMÃO, 2012, p. 157-163, 170-172)2. Ao executar as tarefas propostas nessas etapas, Predestinado torna-se digno de entrar em Jerusalém.

f) Jerusalém, ponto de chegada da peregrinação, onde Predestinado torna-se candidato à cidadania da cidade santa. O Soberano Rei reconhece suas qualidades de peregrino e escreve Predestinado, não só por Cidadão perpétuo de Jerusalém, mas ainda "o perfilhou por filho de Deus, como os demais, pondo nele seu Santo nome e de seu Eterno Pai, conforme a verdade de sua promessa, entregando-lhe a

\footnotetext{
${ }^{2}$ As Vias Purgativa, lluminativa e Unitiva são as três etapas necessárias para a ascensão do humano à felicidade perfeita para a qual foi criado: a Via Purgativa se caracteriza pela purificação do ser humano dos obstáculos para a santificação pela Graça; a Via Iluminativa pela luz que surge com a graça de Deus; e a Via Unitiva pela união da alma com Deus. Cf. LAGRANGE, Garrigou R. Las tres edades de la vida interior. Preludio de la del cielo. 3ạ ed. Buenos Aires: Dedebec \& Edicones Desclée de Brouwer, 1944.
} 
herança toda de seu Reino, como herdeiro de Deus e como herdeiro de Cristo para viver, e reinar eternamente com ele e sem receio ou perigo de o perder jamais” (GUSMÃO, 2012, p. 193).

O roteiro de Precito também inclui seis cidades, todas governadas por "nobres e ilustres" senhores, chamadas "personagens nefandas":

a) Bethaven ("casa da Vaidade”), que ainda que "à vista parecia suntuosa, era por dentro vazia, ou de mãos vizinhos", governada por "um antiquíssimo e incestuoso velho chamado Engano, casado com uma irmã bem velha e adúltera por nome Mentira, filhos ambos do Diabo". Esta cidade “sem alicerces” é o início do caminho da perdição de Precito, o qual logo se desfaz do "hábito honesto e santo, com que havia saído do Egito, principalmente a túnica interior, que chamam Graça Baptismal” (GUSMÃO, 2012, p. 64).

b) Samaria, "terra toda de idolatras e pecadores, onde nenhum culto se dava ao verdadeiro Deus", governada por um casal de velhos, Vício, casados com Profanidade, que eram assessorados por três regentes: Concupiscência da carne, Concupiscência dos olhos, e Soberba da vida. Precito acolhe-se num "bairro alto da Cidade, chamado Passatempo, onde não havia outra ocupação mais que jogos, risos e entretenimentos, onde não poucas vezes nasciam mil dissensos; e como a linguagem que se fala de Bethaven é a mesma que se fala em Samaria, em quatro dias foi tido e havido por Samaritano como os demais” (GUSMÃO, 2012, p. 82).

c) Bethoron ("casa de liberdade"), governada "por um homem de baixa qualidade, casado com uma fêmea do mesmo sangue chamada Fantasia": “caminhando pela Rua Larga chamada Liberdade de Consciência, se resolveu a fazer sua jornada pelos malditos montes de Gelboè, que quer dizer inchação, até que, descendo às terras de Efraim todas de Precitos, foi fazer seu assento a uma Cidade do mesmo Efraim, chamada Bethoron, que se interpreta Domus libertatis, casa de liberdade”. Governada por Apetite e Fantasia, nessa cidade Precito desce mais um degrau da escada que o levará ao inferno: ele adapta-se à cidade de tal 
forma, que "mudando o sobrenome de Peregrino, se chamou daí por diante Precito Voluntario" (GUSMÃO, 2012, p. 105).

d) Éden, dirigida por "Regalo, casado com uma fêmea muito delicada e mimosa chamada Delicia, cujo Palácio meneava como Mordomo ou Guarda-mor um moço à primeira vista aprazível e mui prezado de suas Senhorias, chamado Bemmequero". Precito "adoeceu do mal comum da terra, que chamam Mimo, e deste mal se lhe originaram vários achaques, a saber, Preguiça, Descuido, Frouxidão, Tibieza, com que tomou tal fastio aos medicamentos, com que o mimo se cura, convém a saber, penitencia e rigor, que em lhe falando neles, notavelmente se alterava” (GUSMÃO, 2012, p. 131).

e) Babel, "cidade de confusão", onde Precito é recebido "com mil tristezas, desgostos e inquietações". Governada por "dois maliciosos e incestuosos velhos chamados Pecado e Maldade, inimigos e aborrecidos de Deus", nela vivem "sete harpias", ou sete monstros, chamados "Pecados Capitais", que enviam a Precito presentes de boas-vindas: "Soberba lhe enviou sua filha, Própria Estimação, [...] Avareza lhe enviou a seu filho Amor de dinheiro [...] Luxúria lhe enviou Sensualidade, irmã sua, [...] Ira lhe enviou a Vingança, sua filha, [...] Gula lhe mandou a Demasia, sua criada, [...] Inveja lhe mandou sua filha Suspeita [...] Preguiça lhe mandou seu filho primogênito Tédio das Coisas Espirituais". Em Babel, Precito contraiu "o mal da terra", o Esquecimento, e "andava a modo de estúpido, sem Lembranças de Deus, nem da salvação [...] sendo que às coisas temporais e próprias conveniências tinha os sentidos muitos espertos e as potências muitos atentas, por isso sentia por extremo a perda de qualquer cousa temporal e pela perda das eternas nenhum sentimento mostrava” (GUSMÃO, 2012, p. 152-153).

f) Babilônia, cidade das trevas, onde Precito entrou "sem dificuldade alguma, porque de dia e de noite estão suas portas patentes e abertas para entrar, fechadas para sair". Precito é hospedado num bairro que "se chama comumente Inferno, aonde gozasse das delicias, que em Babilônia se costumam". Precito é 
recebido por Belzebú, "Príncipe de Babilônia”, que o sujeita a penas terríveis: “E para que os tormentos fossem proporcionados aos deleites, conforme a lei da Babilônia, e ele, Precito, em toda a sua vida não havia tratado de outra coisa mais que de regalar a carne e de deleitar os sentidos, logo, no mesmo ponto, as visões horrendas dos Demônios lhe começarão a atormentar a vista, as blasfêmias do Criador, os ouvidos; os fedores intoleráveis do lugar, as narinas; os amargores e fel do Inferno, o gosto; os dentes das Serpentes infernais, o tato. Ali, umas vezes o frigiam em azeite, outras o banhavam em metal derretido, outras lhe atravessavam mil vezes o coração sem morrer, outras o faziam em mil pedaços dragões sem acabar; e finalmente tudo, quanto se pode considerar de pena e tormento padecia o miserável Precito, sem remédio, sem alívio, sem mudança” (GUSMÃO, 2012, p. 179-180).

Neste momento chega o tempo do arrependimento para Precito, mas ele clama em vão, reconhecendo os seus erros:

"Oh, maldita seja Própria Vontade, que me enganou os malditos meus filhos, que me tiraram de meu sentido para caminhar por Bethavem e não como vós, por Belém. Quão facilmente pudera ser Bem-aventurado como vós e, como vós, seguisse os passos da Razão! Porém, já sinto com o meu mal, o meu engano, já vejo o fruto da minha loucura, já padeço eternamente o castigo de meus pecados. Com estas e outras palavras, cheio de ira e de confusão naquele eterno pranto e ranger de dentes que Cristo diz no Evangelho persevera ainda hoje o miserável condenado Precito e persevera, assim, enquanto Deus for Deus, por toda a eternidade" (GUSMÃO, 2012, p. 180).

O gráfico abaixo mostra os roteiros que Predestinado Peregrino e Precito passaram em suas respectivas peregrinações: 


\section{Gráfico 1 - Roteiros}

\begin{tabular}{|c|c|}
\hline Predestinado Peregrino & Precito \\
\hline $\begin{array}{l}\text { Belém, cidade onde nasceu o Salvador, } \\
\text { governada por Desengano, casado com a } \\
\text { Verdade. }\end{array}$ & $\begin{array}{l}\text { Bethaven ("casa da Vaidade"), governada } \\
\text { por Engano, casado com Mentira. }\end{array}$ \\
\hline $\begin{array}{l}\text { Nazaré, de onde "se ia direito a } \\
\text { Jerusalém", governada por "Culto } \\
\text { Divino", casado com "Religião". }\end{array}$ & $\begin{array}{l}\text { Samaria ("terra de idólatras"), governada } \\
\text { por Vício, casado com Profanidade. }\end{array}$ \\
\hline $\begin{array}{l}\text { Betânia ("Casa de Obediência”), } \\
\text { governada por Preceito e Obediência. }\end{array}$ & $\begin{array}{l}\text { Bethoron ("casa de liberdade"), } \\
\text { governada por Apetite e Fantasia. }\end{array}$ \\
\hline $\begin{array}{l}\text { Cafarnaum, governada por "Rigor Santo", } \\
\text { casado com "Penitência Justa". }\end{array}$ & $\begin{array}{l}\text { Éden, dirigida por Regalo, casado com } \\
\text { Delicia. }\end{array}$ \\
\hline $\begin{array}{l}\text { Betel (“Casa de Deus"), situada no "Cume } \\
\text { de perfeição" e morada da Caridade. }\end{array}$ & $\begin{array}{l}\text { Babel, governada pelo "Pecado e } \\
\text { Maldade" e onde também vivem os } \\
\text { "Pecados Capitais". }\end{array}$ \\
\hline $\begin{array}{l}\text { Jerusalém, ponto de chegada da } \\
\text { peregrinação e súmula de todas as } \\
\text { perfeições. }\end{array}$ & $\begin{array}{l}\text { Babilônia, onde Precito é recebido por } \\
\text { Belzebú, Príncipe local e se hospeda num } \\
\text { bairro chamado Inferno. }\end{array}$ \\
\hline
\end{tabular}

Fonte: Dados da pesquisa

As etapas percorridas pelos dois irmãos apresentam os caminhos da salvação e da condenação eternas como duas alternativas que se colocam a cada indivíduo: "Eis aqui, devoto Leitor, o fim que teve o nosso Predestinado Peregrino de todos os seus caminhos, eis aqui qual foi o termo de sua peregrinação, agora é bem que confiras com o irmão Precito para que pelo sucesso de um e de outro vejas o caminho que levas, para conhecer o fim que te espera. Todos somos nesta vida peregrinos e algum dia há de chegar o fim de nossa peregrinação, o qual ou há de ser salvação, ou de condenação eterna” (GUSMÃO, 2012, p. 197). A decisão de percorrer os caminhos do mal, representados pelas cidades do Antigo Testamento onde Precito se detém, ou, ao contrário, à semelhança de Predestinado, que segue os caminhos pelos quais Cristo passou, cabe a cada um deles. Os caminhos percorridos por Predestinado são identificados com o itinerário de Cristo na terra 
e, ao longo do seu percurso, ele entra apenas numa cidade que não se enquadra num roteiro do Novo Testamento: Betel, “a única das cidades que em si comporta, sobretudo, ressonâncias do Antigo Testamento”. Betel é incluída por ser a "Cidade mística da perfeição", lugar das vias "purgativa, iluminativa e unitiva”, através das quais se atinge o "alto cume da perfeição, onde Deus habita" (SANTOS, 2004, p. 591).

\section{Conclusão}

O livro História do Predestinado Peregrino e de seu Irmão Precito foi escrito num período que favoreceu a produção de um tipo de literatura que estava voltada para a espiritualidade e para a moral, bem como à difusão e a aceitação das normas e dos princípios que serviam de fundamento à renovação da religião, da espiritualidade e da própria conduta do indivíduo3. Como exemplo de uma literatura espiritual, catequética, a obra de Gusmão almeja colocar o ser humano diante da problemática da salvação, além de ensinar e divertir. Esta forma de "pensar a arte, bem como a eficácia da sua capacidade para influenciar comportamentos, talvez se revele estranha ao leitor atual, para o qual a dimensão argumentativa destes textos narrativos ficcionais resulta certamente anacrônica”, mas "para bem avaliar de todo o potencial persuasivo de obras desta natureza, é necessário que o destinatário se aperceba de que determinados elementos utilizados na sua composição [...] constituem, afinal, processos retóricos específicos, particularmente valorizados pelo autor” (MOREIRA, 2006, p. 319$320)$.

\footnotetext{
${ }^{3}$ Os Exercícios Espirituais (1547), de Inácio de Loyola, tiveram um papel relevante nesta época. Eles definem os parâmetros nos quais os fieis católicos deviam confrontar o inimigo e a corrupção temporal que ele incorpora, para poderem entrar num estado de graça e, assim, obter a salvação. Através de uma complexa interação entre diferentes funções imaginativas, o texto de Loyola é capaz de superpor vários níveis narrativos simultâneos. A fim de reformular a "narrativa maior" (o Magisterium) da fé católica romana além da revelação das Escrituras Sagradas, a obra requer que aquele que faz os "exercícios" torne-se um participante ativo desta narrativa através do contato visual constante com as "ordens de corrupção", isto é, os espaços nos quais a virtude pode ser confrontada com a decadência física e o pecado. Através destes espaços a Contrarreforma romana redefinirá a economia da salvação e difundirá as dinâmicas visuais dos Exercícios Espirituais no mundo católico. Cf. CONROD, Frederic. Baroque Orders of Corruption: Formation, Diffusion, Transformation, and Negation. Loyola's Spiritual Exercises. Tese de doutorado. Boulder, University of Colorado, 2006.
} 
As retóricas de inspiração tridentina valorizavam a dimensão persuasiva do discurso artístico. Os processos destinados a "provocar o deleite estavam subordinados a finalidades práticas que, em última instância, tinham como objetivo alcançar o coração dos fiéis, procurando levá-los a agir em conformidade com os padrões propostos pela mensagem que se queria difundir"; e "ainda que a importância concedida aos processos de captação da atenção dos ouvintes ou dos leitores tenha conduzido a uma tendência para acentuar a presença do delectare, a observância dos ditames da Contra Reforma, aplicados à arte, levou à sua moralização". As narrativas alegóricas deste período, como a História do Predestinado Peregrino e de seu Irmão Precito, compartilham estas características ao refletir e incentivar a preferência por "recursos argumentativos que permitam persuadir e deleitar, com uma propensão para usar a arte com fins de controle e de regulação dos comportamentos tidos por socialmente aceitáveis". Tudo isso supõe a "recorrência a um conjunto de recursos e de estratégias que, pela sua multiplicidade, ilustram o princípio da unidade na diversidade, visto que, a despeito do seu caráter variado, todos pretendem atrair o leitor, impondo-se desse modo como um subtil meio de dominação ética e doutrinal” (MOREIRA, 2006, p. 320; MARAVALL, 1997, p. 119-120).

\section{REFERÊNCIAS}

AGNOLIN, Adone. Jesuítas e selvagens: a negociação da fé no encontro catequéticoritual americano-tupi (séc. XVI-XVII). São Paulo: Humanitas/FAPESP, 2007.

AUGUSTO, Sara. A alegoria na ficção romanesca do maneirismo e do barroco. Lisboa: Calouste Gulbenkian, 2010.

CONROD, Frederic. Baroque orders of corruption: formation, diffusion, transformation, and negation of Loyola's spiritual exercises. 2006. 375 f. Tese (Doutorado) - Graduate School, University of Colorado, Boulder, Colorado.

GUSMÃO, Alexandre de. A novela história do predestinado peregrino e de seu irmão Precito (1682): compêndio de saberes antropológicos e psicológicos dos jesuítas no Brasil Colonial. Marina Massimi (Org.). São Paulo: Edições Loyola, 2012. p. 57-198. 
GUSMÃO, Alexandre de. História do predestinado peregrino e de seu irmão Precito. 2 ed. Évora: Editora da Universidade, 1685. Disponível em: <

http://www.archive.org/details/historiadopredesoogusm >. Acesso em: 20/07/2012.

HANSEN, João Adolfo. Alegoria: construção e interpretação da metáfora. São Paulo: Hedra/Editora da UNICAMP, 2006.

LAGRANGE, Garrigou R. Las três edades de la vida interior: preludio de la del cielo. 3.ed. Buenos Aires: Dedebec \& Edicones Desclée de Brouwer, 1944.

LUBAC, Henri de. The Four Senses of the Scripture. v. 1. Grand Rapids: Eerdmans, 1998.

MARAVALL, José Antônio. A cultura do barroco. São Paulo: EDUSP, 1997.

MOISÉS, Massaud. História da literatura brasileira: das origens ao romantismo. 7 ed., v. 1. São Paulo: Cultrix, 2001.

MOREIRA, Maria M. A novela alegórica em português dos séculos XVII e XVIII: o belo a serviço do bem. 2006. 422 f. Tese (Doutorado) - Faculdade de Letras, Universidade do Minho, Minho, Portugal.

SANTO AGOSTINHO. A Doutrina Cristã. São Paulo: Paulus, 2002.

SANTOS, Zulmira C. Emblemática, memória e esquecimento: a geografia da salvação e da condenação nos caminhos do "prodesse ac delectare" na História do Predestinado Peregrino e seu Irmão Precito (1682) de Alexandre de Gusmão SJ [1629-1724]. In: Actas do colóquio A Companhia de Jesus na Península Ibérica. CIUHE, 2004, p. 581599 .

TUCKER, George Hugo. Homo Viator: itineraries of exile, displacement and writings in Renaissance Europe. Genève: Librairie Droz S.A., 2003. 